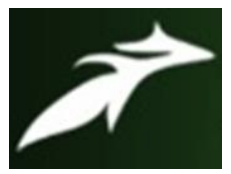

Vibhav Gupta et al, International Journal of Advances in Agricultural Science \& Technology,

Vol.8 Issue.10, October-2021, pg. 105-115

ISSN: 2348-1358

Impact Factor: 6.057

NAAS Rating: 3.77

\title{
CONSTRAINTS FACED BY FARM WOMEN IN AGRICULTURAL OPERATIONS AND ALSO IN DECISION MAKING AND SEEK THEIR SUGGESTIONS FOR BETTER PARTICIPATION
}

\author{
Vibhav Gupta* \\ M.Sc. Ag. (Agricultural Extension \& Communication)* \\ Prof. (Dr.) Ms. Jahanara** \\ Professor \& Head, Department of Agricultural Extension \& Communication, SHUATS Prayagraj Uttar Pradesh** \\ Dr. Dipak Kumar Bose*** \\ Associate Professor, Department of Agricultural Extension \& Communication, SHUATS Prayagraj Uttar Pradesh**** \\ DOI: 10.47856/ijaast.2021.v08i10.012
}

\begin{abstract}
India is a country of great tradition, where social customs and norms exert a firm grip over the behavioral patterns of individuals. Women constitute one of the most important and dynamic but deprived and long neglected sections of the Indian society. For the present study Prayagraj district is selected by purposive sampling because the participation of women in agriculture is comparatively more than the other districts of Uttar Pradesh. There are 20 blocks in the selected district out of that, Kaudihaar block is selected by purposive sampling because maximum numbers of women are engaged in agriculture. One hundred twenty farmers were selected from 8 villages. Data were collected by using pre-tested schedule and analyzed using appropriate statistical tools. Lacks of family support, lack of knowledge, dominance of male members in the family are the constraints faced by farm women. Farm women faced major constraints in decision making process about various agriculture related activities were: social/cultural norms and lack of self confidence in decision. Empowerment of women in developing countries like India will lead the nation to a breaking issue of humanist thinking for globalization. The major suggestions offered by farm women to overcome the constraints were more technical guidance regarding scientific farming should be given to farm women and training should be imparted at village level.
\end{abstract}

Keywords: Women, Knowledge, dominance, constraints etc. 


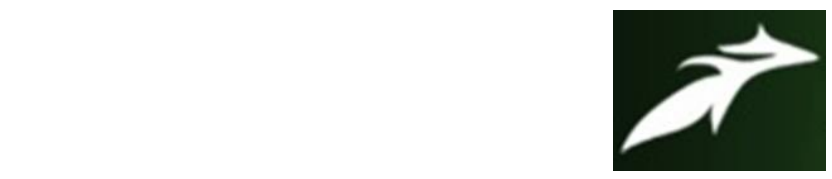

Vibhav Gupta et al, International Journal of Advances in Agricultural Science \& Technology, Vol.8 Issue.10, October-2021, pg. 105-115

ISSN: 2348-1358

Impact Factor: 6.057

NAAS Rating: 3.77

\section{INTRODUCTION}

The role of women has to be visual and as described in the words of Tagore in chitra, "I am not goddess to be worshiped, nor yet the object common pity to be brushed aside like a moth within difference, if you desire to keep me by your side in the path of danger and daring, if you allow me to shave the great duties, of your life them you will know my true self". It acknowledged that women is the first agriculturist in the world. When men were basically hunters, it was the woman who collected the grains, fruits, and cooked food for the man and after the domestic animals like cattle, sheep, goats, poultry etc. throughout the history of man till today, woman directly or indirectly influenced the course of agriculture and animal husbandry. In developing countries like India 81percent of the rural women depends upon agriculture either as cultivators or as labourers and participate in several activities, such as sowing, transplanting, weeding, fertilizer application, plant protection, thinning, harvesting processing selling, winnowing, storing, looking after the animals, kitchen gardening etc.

Several of these operations are exclusively carried out by women only. The role of women in agriculture varies on the socio-economic status of the families, regional differences, cropping and animal husbandry patterns etc. The nutrition of the family entirely depends upon the vision and the activities of the women. while woman plays most significant role in agriculture, her participation is taken for granted in the male dominated societies India achieved self reliance in food grains with the ushering in of green-revolution. Since independence, we tripled the population of food grains which is helping us not only to meet the internal requirements but also to build up large quantities of buffer stocks to meet any exigencies. We increased production of wheat, rice, cotton, potato, milk, meat, fish, poultry products etc...several folds in the last few decades of our independence.

The ICAR has also initiated and sponsored programmes and projects in home science mainly with the purpose of helping rural women overcome malnutrition, disease and socio-economic 


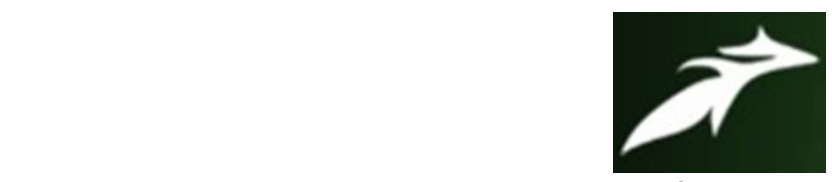

Vibhav Gupta et al, International Journal of Advances in Agricultural Science \& Technology, Vol.8 Issue.10, October-2021, pg. 105-115

ISSN: $2348-1358$

Impact Factor: 6.057

NAAS Rating: 3.77

constants involved in their development. At all India coordinated research project on home science is being operated at 6 centers in the country viz., Ludhiana, Hisar, Udaipur, pantnagar, Hyderabad and Dharwad.

The ICAR has initiated four transfer of technology project viz. National Demonstrations Project, Operational Research projects, Krishi Vigyan Kendra and lab-to-lab programme which are all ready serving the farming communities by making new technologies available in their dear-steps. The KVKs and the ORPs on scheduled castes and scheduled tribes are specially directed towards development of socio-economically deprived class of farmers including from women.

The council has established $24 \mathrm{KVKs}$ in Andhra Pradesh which impart necessary skills to the practicing farmers and farm women girls in agriculture and allied professions like poultry keeping fisheries, piggery, sericulture, mushroom cultivation, goatry, rabitry etc..the farm women and rural girls are also trained in the preparation of nutritional but low cost receipes from locally available food materials, post harvest-technology, storage of grain, failoring, knitting etc...in the last one decade, the kvks have organized $4.65 \%$ training programmes exclusively for farm women and rural girls. These training programmes have benefited over 1,22,000 female participation in different skills.

According to Swaminathan, the famous agricultural scientist, some historians believe that it was woman who first domesticated crop plants and thereby initiated the art and science of farming. While men went out hunting in search of food, women started gathering seeds from the native flora and began cultivating those of interest from the point of view of food, feed, fodder, fibre and fuel. Women are considered to be pioneers in all sorts of development, as they play a key role in shaping the character of young generation whom we call as the future of the nation. Women contribute nearby equally along with men. In the economic development of our country and hence the prosperity and growth of a nation depends on the status and development of women. 


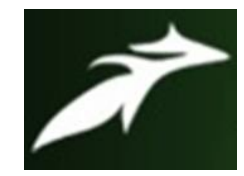

Vibhav Gupta et al, International Journal of Advances in Agricultural Science \& Technology, Vol.8 Issue.10, October-2021, pg. 105-115

ISSN: 2348-1358

Impact Factor: 6.057

NAAS Rating: 3.77

\section{RESEARCH METHODOLOGY}

The present study was conducted in Kaudihaar block of Prayagraj district of Uttar Pradesh. Descriptive research design was followed for the analysis. The study was based on primary \& secondary data. The data was collected from respondents by using the pre structured interview schedule. Data analysis is done through frequency and percentage distribution using statistical tools.

For calculating percentage, frequency was multiplied by 100 and divided by total number of Respondents.

$$
\mathrm{P}=\mathrm{X} / \mathrm{N} \times 100
$$

Where,

$\mathrm{P}=$ Percentage

$\mathrm{X}=$ Frequency of the Respondents

$\mathrm{N}=$ Total number of Respondents

\section{RESULTS \& DISCUSSION}

\section{Constraint in participation of farm women:}

The constraint reported by the farm women in respect of participation process indicated that the constraints are of varied type and in-various intensity also. The details of constraints were listed in table 1. 


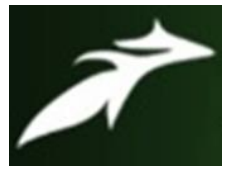

Vibhav Gupta et al, International Journal of Advances in Agricultural Science \& Technology,

Vol.8 Issue.10, October-2021, pg. 105-115

ISSN: 2348-1358

Impact Factor: 6.057

NAAS Rating: 3.77

Table. 1: Constraints perceived by farm women in participation process.

\begin{tabular}{|c|c|c|c|c|}
\hline S. No. & Constraints & Frequency & Percentage & Rank \\
\hline 1. & $\begin{array}{c}\text { Maximum time devotion in } \\
\text { household work }\end{array}$ & 80 & 66.66 & IV \\
\hline 2. & Family norms & 75 & 62.50 & $\mathbf{V}$ \\
\hline 3. & Lack of knowledge & 90 & 75.00 & II \\
\hline 4. & $\begin{array}{c}\text { Perplexity of time for farm and } \\
\text { home activities }\end{array}$ & 35 & 29.16 & XII \\
\hline 5. & Afraid of work performance & 40 & 33.33 & $\mathbf{X}$ \\
\hline 6. & $\begin{array}{l}\text { Dominance of male members } \\
\text { in the family }\end{array}$ & 70 & 58.33 & VI \\
\hline 7. & $\begin{array}{l}\text { No permission to women for work } \\
\text { performance due to } \\
\text { younger age }\end{array}$ & 30 & 25.00 & XIII \\
\hline 8. & $\begin{array}{l}\text { Lack of confidence to } \\
\text { agricultural activities }\end{array}$ & 38 & 23.33 & $\mathbf{X I}$ \\
\hline
\end{tabular}




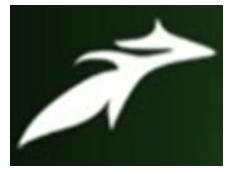

Vibhav Gupta et al, International Journal of Advances in Agricultural Science \& Technology, Vol.8 Issue.10, October-2021, pg. 105-115

ISSN: 2348-1358

Impact Factor: 6.057

NAAS Rating: 3.77

\begin{tabular}{|c|c|c|c|c|}
\hline 9. & $\begin{array}{l}\text { Lack of information about the } \\
\text { resources of availability and use of it }\end{array}$ & 50 & 41.66 & VIII \\
\hline 10. & Lack of proper guidance & 60 & 50.00 & VII \\
\hline 11. & $\begin{array}{l}\text { Inability in anticipating them } \\
\text { possible repercussions of the work } \\
\text { performance }\end{array}$ & 45 & 37.50 & IX \\
\hline 12. & Physical stress and strain & 85 & 70.83 & III \\
\hline 13. & Lack of family support & 95 & 79.16 & $\mathbf{I}$ \\
\hline 14. & Non interested in agricultural activities & 25 & 20.83 & XIV \\
\hline & Average & 58.43 & 48.09 & \\
\hline
\end{tabular}

Table 1 indicates the constraints perceived by the farm women in their participation in agricultural activities. The average percentage of further constraint perceived by farm women in their participation was 48.09. The percentage of one, two, three, six, ten, twelve and thirteen 


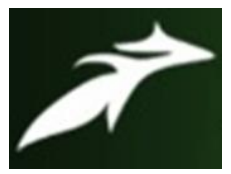

Vibhav Gupta et al, International Journal of Advances in Agricultural Science \& Technology, Vol.8 Issue.10, October-2021, pg. 105-115

ISSN: 2348-1358

Impact Factor: 6.057

NAAS Rating: 3.77

were higher than the percent of average i.e. 48.09. This means that these seven constraints were more important as compared to other.

As per the frequency level of farm women opinion in respect of constraints confronting in participation process and got rank accordingly, the item wise were lack of family support rank first, lack of knowledge rank second, physical stress and strain rank third, maximum time devotion in household work rank fourth, family norms rank fifth, dominance of male members in the family rank sixth, lack of proper guidance rank seventh, lack of information about the resources of availability and use of it rank eighth, inability in anticipating them possible repercussions of the work performance rank ninth, afraid of work performance rank tenth, lack of confidence to agricultural activities rank eleventh, perplexity of time for farm and home activities rank twelfth, No permission to women for work performance due to younger age rank thirteen and non-interested in agricultural activities rank fourteenth respectively.

\section{Constraint in decision making pattern of farm women:}

The decision making in agricultural process is the important task for resource use efficiency and managerial skill. Table 2 represents the constraints by women in decision making pattern.

Table. 2 Constraints perceived by farm women in decision making pattern.

\begin{tabular}{|c|c|l|l|l|}
\hline S. No. & Constraints & Frequency & Percentage & Rank \\
\hline 1. & Maximum time devotion in & 80 & 66.66 & IV \\
\hline household work & Family norms & 75 & 62.50 & V \\
\hline 3. & Lack of knowledge & 90 & 75.00 & I \\
\hline 4. & $\begin{array}{c}\text { Perplexity of time for farm and } \\
\text { home activities }\end{array}$ & 35 & 29.16 & XIII \\
\hline
\end{tabular}




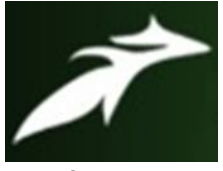

Vibhav Gupta et al, International Journal of Advances in Agricultural Science \& Technology,

Vol.8 Issue.10, October-2021, pg. 105-115

ISSN: 2348-1358

Impact Factor: 6.057

NAAS Rating: 3.77

\begin{tabular}{|c|c|c|c|c|}
\hline 5. & $\begin{array}{l}\text { Afraid of making any } \\
\text { improvement in farming }\end{array}$ & 40 & 33.33 & XI \\
\hline 6. & $\begin{array}{l}\text { Dominance of male members } \\
\text { in the family }\end{array}$ & 70 & 58.33 & VI \\
\hline 7. & Lack of education & 86 & 71.66 & II \\
\hline 8. & $\begin{array}{c}\text { No permission to take } \\
\text { decisions due to younger age }\end{array}$ & 30 & 25.00 & XIV \\
\hline 9. & $\begin{array}{c}\text { Lack of confidence to take } \\
\text { Decision }\end{array}$ & 38 & 23.33 & XII \\
\hline 10. & $\begin{array}{l}\text { Inability to take decision due } \\
\text { to contingent problems }\end{array}$ & 55 & 45.85 & IX \\
\hline 11. & $\begin{array}{c}\text { Lack of information about the } \\
\text { sources of availability of resources } \\
\text { to solve the } \\
\text { Problems }\end{array}$ & 60 & 50.00 & VIII \\
\hline 12. & $\begin{array}{l}\text { Inability in diagnosing the problems } \\
\text { about which } \\
\text { decisions is to be taken }\end{array}$ & 65 & 54.16 & VII \\
\hline 13. & $\begin{array}{l}\text { Lack of adequate information } \\
\text { about the solution to } \\
\text { problems }\end{array}$ & 25 & 20.83 & $\mathrm{XV}$ \\
\hline 14. & $\begin{array}{c}\text { Lack of proper guidance for } \\
\text { taking decision }\end{array}$ & 45 & 37.50 & $\mathrm{X}$ \\
\hline & & & & \\
\hline
\end{tabular}




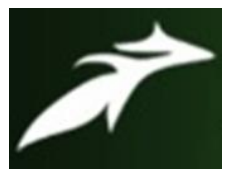

Vibhav Gupta et al, International Journal of Advances in Agricultural Science \& Technology, Vol.8 Issue.10, October-2021, pg. 105-115

ISSN: 2348-1358

Impact Factor: 6.057

NAAS Rating: 3.77

\begin{tabular}{|c|c|c|c|l|}
\hline 15. & $\begin{array}{c}\text { Inability in anticipating then } \\
\text { possible repercussions of the } \\
\text { decision taken }\end{array}$ & 85 & 70.83 & III \\
\hline Average & $\mathbf{5 8 . 6 0}$ & $\mathbf{4 8 . 2 8}$ & \\
\hline
\end{tabular}

The average percentage of further constraint perceived by farm women in their decision making pattern was 48.28. The Percentage of one, two, three, six, seven, eleven, twelve and fifteen were higher than the percent of average i.e. 48.28. This means that these eight constraints were more important as compared to other.

As per the frequency level of farm women opinion in respect of constraints faced by them in respect of decision making in agricultural activities and got rank accordingly, the item views were lack of knowledge rank first, lack of education rank second, inability in anticipating then possible repercussions of decision taken rank third, maximum time devoted in household work rank fourth, family norms rank fifth, dominance of male members in the family rank sixth, inability in diagnosing the problems about which decision is to be taken rank seventh, lack of information about the sources of availability of resources to solve the problems rank ninth, lack of proper guidance for taking decision rank tenth, afraid of making any improvement in farming ranked eleventh, lack of confidence to take decision rank twelveth, perplexity of time for farms and home activities rank thirteenth, no permission to take decision due to younger age rank fourteenth and in last, lack of adequate information about the solution to problems rank fifteenth.

\section{Suggestions expressed by farm women regarding participation and decision making pattern.}

1. Training

2. Education

3. Separate school

4. Parent co- operation

5. Good transport facility

6. Proper guidance 


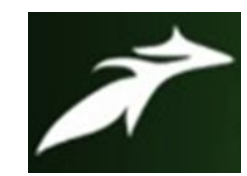

Vibhav Gupta et al, International Journal of Advances in Agricultural Science \& Technology, Vol.8 Issue.10, October-2021, pg. 105-115

ISSN: 2348-1358

Impact Factor: 6.057

NAAS Rating: 3.77

\section{Family support}

8. Creating interest towards agriculture

The average percentage of further constraint perceived by farm women in their suggestions was 65.10. The percentage of one, two, four, five and six, were higher than the per cent of average i.e. 65.10. This means that these five constraints were more important as compared to other.

As per the frequency level of the suggestion expressed by the farm women training module is fully necessary in agricultural activities. Overall 75.00 per cent farm women suggest that they required the training of modern technology in agriculture and this was in first rank. As per the other suggestions expressed by the farm women the education which was suggested by 72.50 per cent farm women, this was in second rank, parents co- operation was suggested by 71.66 per cent farm women, this was in third rank, proper guidance was suggested by 68.33 per cent farm women, this was ranked fourth, good transport facility was suggested by 66.66 per cent farm women ranked fifth, family support was suggested by 62.50 per cent farm women ranked sixth, creating interest towards agriculture was suggested by 58.33 per cent farm women ranked seventh and separate school was suggested by 45.83 per cent farm women ranked eighth.

\section{CONCLUSION}

It is concluded that India is a country of great tradition, where social customs and norms exert a firm grip over the behavioral patterns of individuals. Women constitute one of the most important and dynamic but deprived and long neglected sections of the Indian society. It was found that Farm women faced major constraints in decision making process about various agriculture related activities were: social/cultural norms and lack of self confidence in decision. The major suggestions offered by farm women to overcome the constraints were: more technical guidance regarding scientific farming should be given to farm women and training should be imparted at village level. It was suggested that Efforts should be need to raise the literacy rate of rural women through adult education programme. Area specific cottage and allied agricultural 


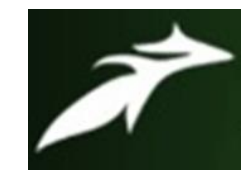

Vibhav Gupta et al, International Journal of Advances in Agricultural Science \& Technology, Vol.8 Issue.10, October-2021, pg. 105-115

ISSN: $2348-1358$

Impact Factor: 6.057

NAAS Rating: 3.77

industries should be developed where in rural women could develop their skills and Appropriate training for raising skill should be given to farm women according to their need.

\section{REFERENCES}

[1]. Adhikari, G. (2007). Knowledge and adoption behaviour of rice growers in Hoshangabad district of Madhya Pradesh. M.sc(Ag.) Thesis, R.A.K college of Agriculture, J.N.K.V.V.,Jabalpur.

[2]. Bhosale, U.S. (2010), Participation of rural youth in paddy farming in Anand district of Gujarat state. M.Sc. (Agri.) thesis, AAU, Anand.

[3]. Chauhan, N. M. (2011). Participation of the tribal farm women in crop management. Agriculture Update, Vol. 6 (3 \& 4), pp:210-212.

[4]. Dhole, G. B. (2009). Impact of dairy programme on dairy farm women. M.Sc. (Agri.) thesis (Unpublished), AAU, Anand.

[5]. Joshi, P.J. (2004). Extent of knowledge and adoption of farmers about modern practice of cotton in Bhal area of Gujarat. M.Sc. (Agri.) thesis, G.A.U., Anand Campus, Anand.

[6]. Leigh C.A, Travis W.R and Kay M.G (2016), "Husband and Wife Perspectives on Farm Household Decision Making Authority and Evidence On Intra-Household" Journal Of Rural Development.

[7]. Manju Suman (2008). Participation of rural women under households and farm activities. Indian Journal of Agriculture Research, 42(1): 37-41.

[8]. Narmatha, N., Uma, V., Arun, L., and Geetha, R. (2009). Level of participation of women In livestock farming activities. Tamilnadu Journal of Veterinary \& Animal Sciences, 5(I), PP:4-8.

[9]. Par Ray, M. N. and chowdhary, R. K. (2004). Variables influencing the participation of scheduled caste women in animal husbandry activities in the Hajo Development block of Assam, Rural India, Feb.- March, pp: 56-59. mar, P.P. (2006), A study on knowledge and extent of adoption of recommended paddy Growers in khambat Taluka of Anand District, M.Sc. (Agri.) Thesis (Unpublished), AAU, Anand.

[10].Singh A.G, Poonia.U, and Jyani.U (2014)," Role of Women in Decision-Making process in Agriculture Sector", International Journal of Scientific and Research Publications, Volume 4. 